\begin{tabular}{ccc}
\hline & $\begin{array}{c}\text { International Journal of Health Services } \\
\text { Research and Policy } \\
\text { www.dergipark.org.tr/ijhsrp }\end{array}$ \\
$\begin{array}{c}\text { INESEG } \\
\text { ENERNATIONAL } \\
\text { SCIENCERING } \\
\text { EDUCATION GROUP }\end{array}$ & e-ISSN: $2602-3482$ & IJHSRP \\
\hline RECHION
\end{tabular}

Research Article

\title{
HISTOPATHOLOGICAL FINDINGS AND CLINICAL OUTCOMES OF PATIENTS AFTER LAPAROSCOPIC SLEEVE GASTRECTOMY
}

\author{
Muhammed Rasid Aykota ${ }^{1}{ }^{(1 D}$, Sevda Yilmaz ${ }^{1}$ (D) \\ ${ }^{1}$ Department of General Surgery, Pamukkale University Faculty of Medicine, Denizli, Turkey \\ Corresponding author: muhammedaykota@hotmail.com
}

\begin{abstract}
Laparoscopic sleeve gastrectomy (LSG) has become an increasingly common method for surgical treatment of morbid obesity in recent years. This study aimed to evaluate the histopathological findings of gastrectomy specimens obtained in LSG and the clinical outcomes of patients. Between June 2018 and December 2019, the resected gastric samples of 170 patients with LSG underwent histopathological examination. Histopathologic examination is routinely performed on the gastric specimen that is resected during the sleeve gastrectomy for histopathologic examinations of the severity of inflammation, atrophy, intestinal metaplasia, and $H$. pylori infection. We found that the most common histopathological findings were chronic gastritis (58.2\%), normal gastric mucosa (17.6\%), and chronic active gastritis (12.4\%). Patients with normal gastric histopathology after LSG lost more weight at the end of the 1st, 3rd, 6th, and 12th months than those with abnormal histopathological findings (chronic gastritis, chronic active gastritis, and edema congestion). Histopathologic examinations are extremely necessary for diagnosing lesions that may have been missed in endoscopies before sleeve gastrectomy. Many factors, such as age, sex, histopathology of the removed stomach, and H. pylori positivity, should be considered in predicting postoperative weight loss success.
\end{abstract}

Keywords: Obesity, Sleeve Gastrectomy, Bariatric Surgery

\begin{tabular}{ll} 
Received: May 5, $2020 \quad$ Accepted: June 03, 2020 \\
\hline
\end{tabular}

\section{Introduction}

Obesity is a common condition that leads to chronic diseases, and it causes deaths due to many complications, including diabetes, cardiovascular diseases, cancer, and related comorbid diseases. Worldwide statistics represent that, more than 1.9 billion adults (39\%) were considered overweight, and approximately 650 million (13\%) were obese. In Turkey, $32.1 \%$ of adults were reported to be obese [1].

Nutritional changes applied for weight control, physical exercise, and obesity drugs are deemed insufficient in combating obesity, resulting in weight gain again after a short time [2]. Bariatric surgery has additional benefits over conventional health style modifications by reducing the stomach volume by decreasing the caloric intake or using restrictive procedures, or by decreasing the intestinal absorption by shortening the small intestine. For the past two decades, a laparoscopic sleeve gastrectomy (LSG) has emerged as the most popular bariatric surgery procedure worldwide $[3,4]$. 
Stomach samples obtained from bariatric surgery are assumed to be normal, except for unexpected incidental findings. However, this assumption was not supported by histological findings, and only a few studies are available on the histopathology of gastrectomy specimens obtained from bariatric surgery [5-7].

This study aimed to evaluate the histopathological findings of gastrectomy specimens obtained in LSG and the clinical outcomes of patients.

\section{Methods}

We selected our participants according to the $1991 \mathrm{NIH}$ criteria (patients with a body mass index (BMI) of $40 \mathrm{~kg} / \mathrm{m}^{2}$ or BMI of $35 \mathrm{~kg} / \mathrm{m}^{2}$ due to at least one comorbid condition such as arterial hypertension, type 2 diabetes, obstructive sleep apnea (OSA), and dyslipidemia ). Their surgeries and histopathological examinations were performed at a university hospital setting. The ethics committee approved this study. We retrospectively and systematically analyzed the demographic, clinical, and histopathological data obtained from the medical records of all patients who underwent LSG for morbid obesity.

Between June 2018 and December 2019, the resected gastric samples of 170 patients with LSG underwent histopathological examination.

Samples were obtained after vertical resection of the stomach during an LSG. Resection was tailored by using $38 \mathrm{Fr}$ bougie. These samples were permanently sectioned in formalin and examined in general. Representative cross-section blocks of $2 \mathrm{~mm}$ thickness were fixed by formalin and paraffin, stained with hematoxylin and eosin, and examined by pathologists in the form of 2-mm thick-sliced slides. All patients with LSG received a routine Helicobacter pylori test. Slides were also stained with Giemsa to control the microorganisms. Additional pathological findings were examined with additional slides. The inclusion criteria were all patients undergoing LSG. All patients had undergone preoperative endoscopy. We also extracted the pre-operative clinical findings and postsurgical course of the patients. Then, data were entered and analyzed.

Ethical Statement: All procedures performed in studies involving human participants were in accordance with the ethical standards of the institutional and/or national research committee and with the 1964 Helsinki declaration and its later amendments or comparable ethical standards.

This study is approved by Pamukkale University Clinical Research Ethics Committee (60116787020/22711; 19.3.2020).

\section{Statistical Analysis}

Extracted data were analyzed using the Statistical Package (SPSS) version 22.0 (SPSS Inc., Chicago, IL). Differences were considered statistically significant when $p<0.05$. The participants' demographic, clinical, and histopathological characteristics were summarized by descriptive statistics (frequency, percentage, and mean $\pm \mathrm{SD}$ or median and range). We also calculated the means and standard errors and $95 \%$ confidence intervals for continuous variables. Any association between two or more categorical variables was assessed by Chi-square/Fisher exact test as appropriate. In addition, any association between the two independent groups of quantitative variables was examined by unpaired $t$ test or Mann-Whitney U test as applicable. 


\section{Results}

Among 170 patients included in the study, 134 (78.8\%) were female, and the median age was $34.7 \pm 10.5$ (18-70). The mean preoperative BMI was $43.1 \pm 6.7 \mathrm{~kg} / \mathrm{m}^{2}$ (32-67). Males had significantly higher BMI than females $(\mathrm{p}=0.01)$. The average weight loss was $13.5 \pm 3.9(7-31), 24.6 \pm 5.5(15-45)$,

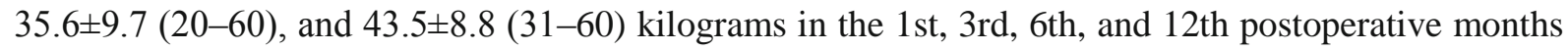
retrospectively. The excess weight loss (\%EWL) were \%24,6(10,5-54,5), \%45,1(21,1-85,7), \%61(27,1$112,5), \% 78,2(40,7-125)$ in the $1^{\text {st }}, 3^{\text {rd }}, 6^{\text {th }}$, and $12^{\text {th }}$ postoperative months retrospectively. In particular, males significantly lost more weight than females in the $1 \mathrm{st}, 3 \mathrm{rd}$, and 6th postoperative months $(\mathrm{p}=0.0$, $\mathrm{p}=0.0$, and $\mathrm{p}=0,001$, respectively) (Table 1$)$.

Table 1. Demographic characteristics and clinical follow-up of patients

\begin{tabular}{|l|c|c|c|c|l|l|l|}
\hline Gender & $\mathrm{N}(\%)$ & $\begin{array}{l}\text { Age } \\
\text { Mean } \pm \mathrm{SD}^{*} \\
(\text { Range })\end{array}$ & $\begin{array}{l}\mathrm{BMI} \\
\mathrm{Mean} \pm \mathrm{SD}^{*} \\
(\mathrm{Rang})\end{array}$ & $\begin{array}{l}\text { First- } \\
\text { month } \\
\text { given } \\
\text { weight } \\
(\mathrm{n}=109)\end{array}$ & $\begin{array}{l}\text { Third } \\
\text { month } \\
\text { given } \\
\text { weight } \\
(\mathrm{n}=79)\end{array}$ & $\begin{array}{l}\text { Sixth } \\
\text { month } \\
\text { given } \\
\text { weight } \\
(\mathrm{n}=42)\end{array}$ & $\begin{array}{l}\text { First- } \\
\text { year } \\
\text { given } \\
\text { weight } \\
(\mathrm{n}=11)\end{array}$ \\
\hline Male & 36 & $\begin{array}{c}35.1 \pm 10.01 \\
(19-56)\end{array}$ & $\begin{array}{c}45.7 \pm 6.4 \\
(36-67)\end{array}$ & $\begin{array}{c}16.3 \pm 5.7 \\
(8-31)\end{array}$ & $\begin{array}{c}29.8 \pm 7.7 \\
(18-45)\end{array}$ & $\begin{array}{c}44.4 \pm 10.6 \\
(25-60)\end{array}$ & $\begin{array}{c}48 \pm 14.4 \\
(32-60)\end{array}$ \\
\hline Female & 134 & $\begin{array}{c}34.6 \pm 10.7 \\
(18-70)\end{array}$ & $\begin{array}{c}42.3 \pm 6.6 \\
(32-65)\end{array}$ & $\begin{array}{c}12.9 \pm 3.1 \\
(7-25)\end{array}$ & $\begin{array}{c}23.2 \pm 3.8 \\
(15-31)\end{array}$ & $\begin{array}{c}32.9 \pm 7.7 \\
(20-50)\end{array}$ & $\begin{array}{c}41.8 \pm 6.4 \\
(31-52)\end{array}$ \\
\hline P-value & & 0.800 & 0,010 & 0.000 & 0.000 & 0.001 & 0.300 \\
\hline
\end{tabular}

*SD, standard deviation

Of the patients, $34(20 \%)$ had a smoking habit. Preoperative comorbidities were diabetes mellitus (13.6\%), hypertension (9.4\%), OSAS (3.6\%), hypothyroidism (2.4\%), insulin resistance $(1.8 \%)$, factor $\mathrm{V}$ Leiden mutation $(1.2 \%)$, and cardiac disease $(0.6 \%)$. The first most common histopathological finding $(n=99,58.2 \%)$ was chronic gastritis. Regarding the specimens, $30(17.6 \%)$ were normal gastric mucosa, 20 (11.8\%) were edema with congestion, and 15 (12.4\%) were chronic active gastritis. Chronic active gastritis was divided into mild (2.4\%), moderate (7.6\%), and severe (2.4\%) categories according to the amount of chronic inflammatory cells in propria (Figure 1). We also observed rare diagnoses. Other abnormal histopathology cases were incomplete type of intestinal metaplasia, gastrointestinal stromal tumor (GIST, Grade 1), and Dieulafoy's lesion separately. Those patients with these conditions were diagnosed intraoperatively, and the preoperative endoscopy was normal. However, none of these incidental findings had any clinical impact in terms of complications, and these patients remained well postoperatively. 


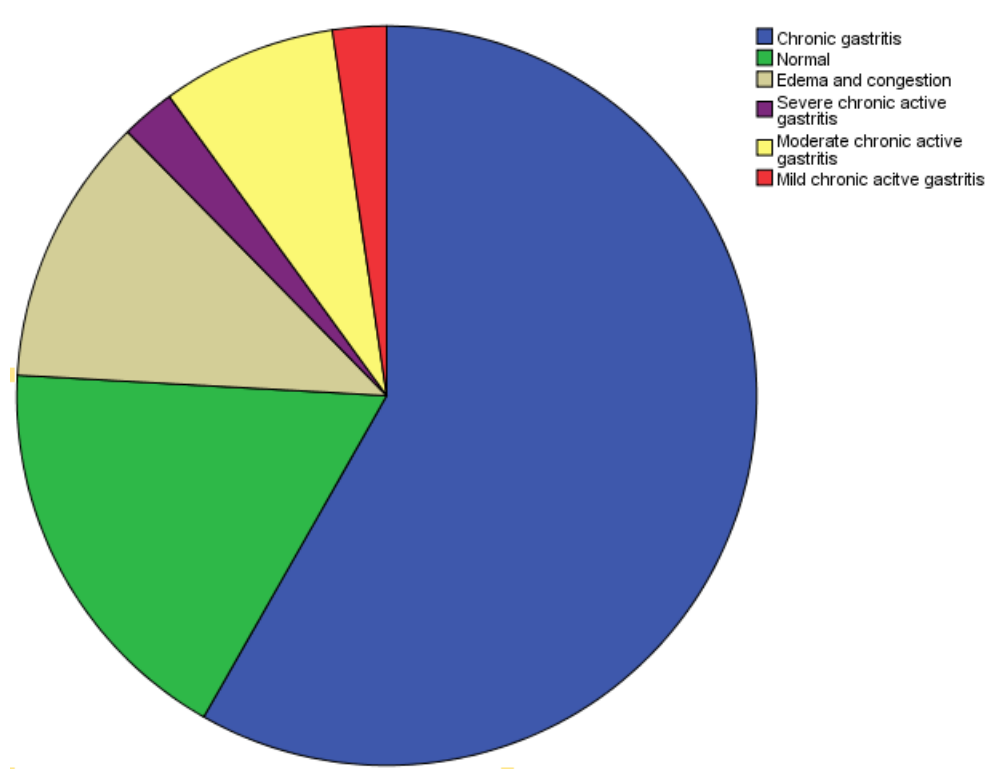

Figure 1. Histopathological findings of the patients

Patients with chronic active gastritis were older and had a higher BMI rate than those with other histopathological findings. In evaluating the histopathological findings according to gender, chronic gastritis was significantly higher in females than in males $(86,64.2 \% ; \mathrm{p}=0.010)$ (Table 2).

Table 2. Histopathological findings according to gender

\begin{tabular}{|l|l|l|l|}
\hline $\begin{array}{l}\text { Histopathological } \\
\text { findings }\end{array}$ & $\begin{array}{l}\text { Female } \\
\text { N (\%) }\end{array}$ & $\begin{array}{l}\text { Male } \\
\text { N (\%) }\end{array}$ & \multirow{2}{*}{ P-value } \\
\hline Normal & $18(60)$ & $12(40)$ & \\
\hline Chronic gastritis & $86(86.9)$ & $13(13.1)$ & \multirow{2}{*}{0.010} \\
\hline Chronic active gastritis & $16(76.2)$ & $5(23.8)$ & \\
\hline Edema congestion & $14(70)$ & $6(30)$ & \\
\hline
\end{tabular}

Patients with normal gastric histopathology after LSG lost more weight at the end of the 3rd, 6th, and 12th months than the others (Table 3). The patients were evaluated in two groups: normal histopathological findings (group 1) and abnormal histopathological findings as chronic gastritis, chronic active gastritis, and edema congestion (group 2). In comparing groups 1 and 2, weight loss was higher in patients with normal histopathological findings at the end of the 1st, 3rd, 6th, and 12th months than those in patients with abnormal findings, and the difference was statistically significant at the 3rd month $(p=0.006)$. 
Table 3. Histopathological findings and clinical follow-up of patients

\begin{tabular}{|c|c|c|c|c|c|c|c|}
\hline $\begin{array}{l}\text { Histopathological } \\
\text { findings }\end{array}$ & $\mathrm{N}(\%)$ & $\begin{array}{l}\text { BMI } \\
\text { Mean } \pm S^{*} \\
\text { (Range) }\end{array}$ & $\begin{array}{l}\text { Age } \\
\text { Mean } \pm \mathrm{SD}^{*} \\
\text { (Range) }\end{array}$ & $\begin{array}{l}\text { First- } \\
\text { month } \\
\text { given } \\
\text { weight } \\
(\mathrm{n}=109)\end{array}$ & $\begin{array}{l}\text { Third } \\
\text { month } \\
\text { given } \\
\text { weight } \\
(\mathrm{n}=79)\end{array}$ & $\begin{array}{l}\text { Sixth } \\
\text { month } \\
\text { given } \\
\text { weight } \\
(\mathrm{n}=42)\end{array}$ & $\begin{array}{l}\text { First- } \\
\text { year } \\
\text { given } \\
\text { weight } \\
(\mathrm{n}=11)\end{array}$ \\
\hline Normal & $\begin{array}{l}30 \\
(17.6)\end{array}$ & $\begin{array}{l}44.3 \pm 6.7 \\
(32-59)\end{array}$ & $\begin{array}{l}34.5 \pm 12.7 \\
(19-64)\end{array}$ & $\begin{array}{l}14 \pm 4.9 \\
(7-31)\end{array}$ & $\begin{array}{l}27.5 \pm 7.5 \\
(20-45)\end{array}$ & $\begin{array}{l}38.2 \pm 11 . \\
7 \\
(20-60)\end{array}$ & $\begin{array}{l}48 \pm 14.4 \\
(32-60)\end{array}$ \\
\hline Chronic gastritis & $\begin{array}{l}99 \\
(58.2)\end{array}$ & $\begin{array}{l}42.6 \pm 6.2 \\
(32-65)\end{array}$ & $\begin{array}{l}33.8 \pm 9.9 \\
(18-64)\end{array}$ & $\begin{array}{l}13.2 \pm 3.5 \\
(7-27)\end{array}$ & $\begin{array}{l}23.9 \pm 4.6 \\
(15-34)\end{array}$ & $\begin{array}{l}34 \pm 8.1 \\
(20-47)\end{array}$ & $\begin{array}{l}41.8 \pm 6.4 \\
(31-52)\end{array}$ \\
\hline $\begin{array}{l}\text { Chronic active } \\
\text { gastritis }\end{array}$ & $\begin{array}{l}21 \\
(12.4)\end{array}$ & $\begin{array}{l}47 \pm 7.5 \\
(40-63)\end{array}$ & $\begin{array}{l}39.7 \pm 10.8 \\
(24-70)\end{array}$ & $\begin{array}{l}13.6 \pm 4.5 \\
(8-25)\end{array}$ & $\begin{array}{l}22.7 \pm 2.9 \\
(18-27)\end{array}$ & $\begin{array}{l}33.5 \pm 4.9 \\
(30-37)\end{array}$ & $42(42)$ \\
\hline $\begin{array}{l}\text { Edema } \\
\text { congestion }\end{array}$ & $\begin{array}{l}20 \\
(11.8)\end{array}$ & $\begin{array}{l}41.05 \pm 8.02 \\
(32-67)\end{array}$ & $\begin{array}{l}34.3 \pm 9.05 \\
(22-54)\end{array}$ & $\begin{array}{l}15.1 \pm 3.8 \\
(9-21)\end{array}$ & $\begin{array}{l}22.2 \pm 3.3 \\
(20-27)\end{array}$ & $\begin{array}{l}33.5 \pm 12 . \\
02(25- \\
42)\end{array}$ & $\begin{array}{l}42 \pm 14.1 \\
(32-52)\end{array}$ \\
\hline $\mathrm{P}$-value & & 0.010 & 0.100 & 0.500 & 0.040 & 0.500 & 0.900 \\
\hline
\end{tabular}

We compared the age, BMI, and weight loss rates in the 1st, 3rd, 6th, and 12 months of $H$. pylori infection. No significant difference was observed according to $H$. pylori positivity (Table 4). Furthermore, H. pylori infection was regarded as a risk factor for chronic active gastritis. However, the two groups had no significant difference in terms of sex (Table 5).

Table 4. Demographic characteristics and clinical follow-up findings compared with H. pylori positivity

\begin{tabular}{|l|l|l|l|}
\hline & H. pylori-positive & H. pylori-negative & P-value \\
\hline Age $($ Mean \pm SD) & $35.4 \pm 9.09(19-51)$ & $34.6 \pm 10.8(18-70)$ & 0.700 \\
\hline BMI (Mean \pm SD) & $45.3 \pm 8.07(35-63)$ & $42.9 \pm 6.6(32-67)$ & 0.100 \\
\hline First-month given weight & $13.2 \pm 4.6(8-25)$ & $13.6 \pm 3.8(7-31)$ & 0.700 \\
\hline $\begin{array}{l}\text { Third-month given } \\
\text { weight }\end{array}$ & $21.5 \pm 3.1(16-27)$ & $25.0 \pm 5.6(15-45)$ & 0.050 \\
\hline $\begin{array}{l}\text { Sixth-month given } \\
\text { weight }\end{array}$ & $35.3 \pm 10.7(23-43)$ & $35.6 \pm 9.8(20-60)$ & 0.900 \\
\hline First-year given weight & $46(46)$ & $43.3 \pm 9.3(31-60)$ & 0.700 \\
\hline
\end{tabular}

Gender and histopathological findings were compared with $\mathrm{H}$. pylori positivity. Results can be followed from Table 5 . 
Table 5. Gender and histopathological findings compared with H. pylori positivity

\begin{tabular}{|l|l|l|l|}
\hline & $\begin{array}{l}\text { H. pylori-positive } \\
\mathrm{N}(\%)\end{array}$ & $\begin{array}{l}\text { H. pylori-negative } \\
\mathrm{N}(\%)\end{array}$ & P-value \\
\hline Gender & $18(13.4)$ & $116(86.6)$ & 0.900 \\
\hline Female & $5(13.9)$ & $31(86.1)$ & \\
\hline Male & & & 0.000 \\
\hline $\begin{array}{l}\text { Histopathological } \\
\text { findings }\end{array}$ & 0 & $30(100)$ & \\
\hline Normal & $8(8.1)$ & $91(91.9)$ & \\
\hline Chronic gastritis & $15(71.4)$ & $6(28.6)$ & \\
\hline Chronic active gastritis & $20(100)$ & \\
\hline Edema and congestion & 0 & & \\
\hline
\end{tabular}

\section{Discussion}

Sleeve gastrectomy is frequently used for obesity treatment worldwide, and it has already been proven as a safe and feasible surgical technique with good postoperative results along with significant improvement in accompanying comorbidities [8].

Histopathologic examination is routinely performed on the gastric specimen that is resected during the sleeve gastrectomy for histopathologic examinations of the severity of inflammation, atrophy, intestinal metaplasia, and $H$. pylori infection. We found that the most common histopathological findings were chronic gastritis (58.2\%), normal gastric mucosa (17.6\%), and chronic active gastritis (12.4\%). According to various studies, the prevalence of histopathological findings of LSG specimens was $13 \%-74.4 \%$ for chronic gastritis, $35.2 \%-69 \%$ for normal histopathology, and $1.6 \%-8.4 \%$ for chronic active gastritis [9-14].

We also discovered rare and important pathological conditions, namely, incomplete type of intestinal metaplasia, GIST (Grade 1) with a microscopically negative margin, and Dieulafoy's lesion, illustrating the importance of postoperative histopathological follow-up.

GIST, which has an incidence of approximately 1/100,000 for all individuals, has a considerably higher incidence in patients undergoing bariatric surgery $(0.3 \%-1.2 \%)$. In all of these studies with unexpectedly higher GIST grade, stromal tumors were not found in preoperative evaluation but during or postoperative histopathologic examination [15-18].

According to gender, age, and BMI were associated with chronic gastritis. Chronic gastritis was significantly higher in female elderly patients, but a higher BMI rate was found in males. Similar to our study, Safahaan et al. [19] reported that chronic active gastritis is associated with the female gender. Hence, obesity may be a risk factor for gastritis, and it is seen more frequently in women $[19,20]$. We found that males significantly lost more weight than females in the 1st, 3rd, and 6th months after surgery. 
Similar to our study, 1012 patients with sleeve gastrectomy were evaluated and found to have a negative correlation between weight loss in females at 3 months [21].

Patients with normal gastric histopathology after LSG lost more weight at the end of the 1st, 3rd, 6th, and 12th months than those with abnormal histopathological findings (chronic gastritis, chronic active gastritis, and edema congestion). Previous studies that compared normal gastric histopathological findings with other histopathologies in terms of weight loss are unavailable. However, Erkinuresin et al. [22] reported that younger patients who had low BMI and inactive gastritis and underwent LSG could achieve more successful weight loss results than the older ones.

Globally, H. pylori infection is responsible for chronic bacterial infection, and most of the affected individuals are asymptomatic [23]. Some patients may develop gastritis, duodenitis, peptic ulcer, and other benign and malignant diseases [24-26].

Considering the high prevalence of $H$. pylori infection in our general community, our study results showed that $H$. pylori infection was diagnosed in $13.5 \%$ of our LSG specimens. This rate is higher than in the USA, Kuwait, and New Zealand (5.2\%, 7.3\%, and 8.6\%, respectively) [12-14]. In other studies conducted in the Middle Eastern populations, H. pylori infection demonstrated a high prevalence (20\%-97\%) [24]. The prevalence of $\mathrm{H}$. pylori in the obese population was $20 \%-50 \%$, which is higher than our study $(13.5 \%)[13,27,28]$. We found that $H$. pylori infection is a risk factor for chronic active gastritis. Previous studies have similarly shown associations of $H$. pylori with chronic active gastritis [29-30].

We observed that the age, BMI, and weight loss rates of patients in the 1st, 3rd, 6th, and 12th months were not associated with $H$. pylori infection.

\section{Conclusion}

Histopathologic examinations are extremely necessary for diagnosing lesions that may have been missed in endoscopies before sleeve gastrectomy. LSG may be performed either as part of a staged approach or as a primary bariatric procedure in patients with obesity. Many factors, such as age, sex, histopathology of the removed stomach, and H. pylori positivity, should be considered in predicting postoperative weight loss success.

Ethical Statement: All procedures performed in studies involving human participants were in accordance with the ethical standards of the institutional and/or national research committee and with the 1964 Helsinki declaration and its later amendments or comparable ethical standards.

This study is approved by Pamukkale University Clinical Research Ethics Committee ( 60116787 020/22711; 19.3.2020).

\section{Acknowledgment}

The authors would like to thank Enago for the English language review.

Informed consent was obtained from all individual participants included in the study.

The authors declare that they have no conflict of interest.

The compliance to the Research and Publication Ethics: This study was carried out in accordance with the rules of research and publication ethics. 


\section{References}

[1] WHO | Overweight and obesity [Internet]. WHO. [cited 2019 Nov 22]. Available from: http://www.who.int/gho/ncd/risk_factors/overweight/en/.

[2] Solomon CG, Dluhy RG. "Bariatric surgery--quick fix or long-term solution?" N Engl J Med. 351(26), 2751-3, 2004.

[3] Sjöström L, Lindroos AK, Peltonen M, et al. "Lifestyle, diabetes, and cardiovascular risk factors 10 years after bariatric surgery", N Engl J Med. 351(26), 2683-93, 2004.

[4] Buchwald H, Oien DM. "Metabolic/bariatric surgery Worldwide 2008" Obes Surg., 19(12), 160511,2009

[5] Onzi TR, d'Acampora AJ, de Araújo FM, et al. "Gastric histopathology in laparoscopic sleeve gastrectomy: Pre- and post-operative comparison." , Obes Surg. 24(3), 371-6, 2014

[6] Ge L, Moon RC, Nguyen H, de Quadros LG, Teixeira AF, Jawad MA. "Pathologic findings of the removed stomach during sleeve gastrectomy." Surg Endosc. 15,1-5, Feb 2019

[7] Vrabie CD, Cojocaru M, Waller M, Sindelaru R, Copaescu C. "The main histopathological gastric lesions in obese patients who underwent sleeve gastrectomy." Dicle Medical Journal/Dicle Tip Dergisi. 1,37(2), 2010

[8] Schirmer B, Schauer PR. "The surgical management of obesity." In: Brunicardi F, Andersen D, Hunter J, et al., editors. Schwartz's principles of surgery in the dition. USA: McGraw-Hill Companies; 2010. p. 952-3. In: Brunicardi F, Andersen D, Hunter J, et al., editors, editor. Schwartz's principles of surgery. 952-3, 2016

[9] Ohanessian SE, Rogers AM, Karamchandani DM." Spectrum of gastric histopathologies in severely obese American patients undergoing sleeve gastrectomy." Obes Surg. 26(3), 595-602, 2016

[10] AbdullGaffar B, Raman L, Khamas A, AlBadri F. "Should We Abandon Routine Microscopic Examination in Bariatric Sleeve Gastrectomy Specimens?" Obes Surg., 26(1), 105-10, 2016

[11] Clapp B. "Histopathologic findings in the resected specimen of a sleeve gastrectomy. " JSLS. 19(1), e2013.00259, 2015

[12] Raess PW, Baird-Howell M, Aggarwal R, Williams NN, Furth EE. "Vertical sleeve gastrectomy specimens have a high prevalence of unexpected histopathologic findings requiring additional clinical management." Surg Obes Relat Dis Off J Am Soc Bariatr Surg., 11(5), 1020-3, 2015

[13] Almazeedi S, Al-Sabah S, Al-Mulla A, et al. "Gastric histopathologies in patients undergoing laparoscopic sleeve gastrectomies." Obes Surg., 23(3), 314-9, 2013

[14] Lauti M, Gormack SE, Thomas JM, Morrow JJ, Rahman H, MacCormick AD. "What Does the Excised Stomach from Sleeve Gastrectomy Tell us?" Obes Surg., 26(4), 839-42, 2016

[15] Yuval JB, Khalaileh A, Abu-Gazala M, et al. "The true incidence of gastric GIST-a study based on morbidly obese patients undergoing sleeve gastrectomy." Obes Surg., 24(12), 2134-7, 2014

[16] Kinsinger LA, Garber JC, Whipple O. "A Review of sleeve gastrectomy specimen histopathology." Am Surg., 82(11), 1101-4, 2016

[17] Chiappetta S, Theodoridou S, Stier C, Weiner RA. "Incidental finding of GIST during obesity surgery." Obes Surg., 25(3), 579-83, 2015 
[18] Tryggvason G, Gíslason HG, Magnússon MK, Jónasson JG. "Gastrointestinal stromal tumors in Iceland, 1990-2003: the icelandic GIST study, a population-based incidence and pathologic risk stratification study." Int J Cancer., 117(2), 289-93, 2005

[19] Safaan T, Bashah M, El Ansari W, Karam M. "Histopathological changes in laparoscopic sleeve gastrectomy specimens: Prevalence, risk factors, and value of routine histopathologic examination." Obes Surg., 27(7), 1741-9, 2017

[20] Yamamoto S, Watabe K, Takehara T. "Is obesity a new risk factor for gastritis?" Digestion,' $85(2), 108-10,2012$

[21] Masrur M, Bustos R, Sanchez-Johnsen L, et al. "Factors associated with weight loss after metabolic surgery in a multiethnic sample of 1012 patients." Obes Surg., 30, 975-981, 2020

[22] Erkinuresin T, Demirci H, Cayci HM, Erdogdu UE. "The relationship between histopathologic findings and weight loss in laparoscopic sleeve gastrectomy." Obes Surg. 30(2), 478-482, 2020.

[23] Suerbaum S, Michetti P. "Helicobacter pylori Infection." N Engl J Med. 347(15), 1175-86, 2002

[24] Khedmat H, Karbasi-Afshar R, Agah S, Taheri S. "Helicobacter pylori Infection in the general population: A Middle Eastern perspective." Casp J Intern Med. 4(4), 745-53, 2013

[25] Eshraghian A. "Epidemiology of Helicobacter pylori infection among the healthy population in Iran and countries of the Eastern Mediterranean Region: a systematic review of prevalence and risk factors." World J Gastroenterol. 20(46), 17618-25, 2014

[26] Khalilpour A, Kazemzadeh-Narbat M, Tamayol A, Oklu R, Khademhosseini A. "Biomarkers and diagnostic tools for detection of Helicobacter pylori." Appl Microbiol Biotechnol. 100(11), 472334,2016

[27] Albawardi A, Almarzooqi S, Torab FC. "Helicobacter pylori in sleeve gastrectomies: prevalence and rate of complications." Int J Clin Exp Med. 6(2), 140-3, 2013

[28] Carabotti M, D’Ercole C, Iossa A, Corazziari E, Silecchia G, Severi C. "Helicobacter pylori infection in obesity and its clinical outcome after bariatric surgery." World J Gastroenterol. 20(3), $647-53,2014$

[29] Leung WK, Ng EKW, Chan WY, Auyeung ACM, Chan K-F, Lam CCH, et al. "Risk factors associated with the development of intestinal metaplasia in first-degree relatives of gastric cancer patients." Cancer Epidemiol Biomark Prev Publ Am Assoc Cancer Res Cosponsored Am Soc Prev Oncol. 14(12), 2982-6, 2005

[30] Chen XY, Liu WZ, Shi Y, Zhang DZ, Xiao SD, Tytgat GNJ. "Helicobacter pylori associated gastric diseases and lymphoid tissue hyperplasia in gastric antral mucosa." J Clin Pathol. 55(2), $133-7,2002$ 